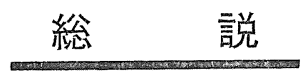

\title{
界面活性剤の動向について
}

\author{
川上八十太
}

川研フォインケミカル株式会社（東京都中央区日本橋小舟町 2-1)

\section{Trend of Surfactant Industry in Japan}

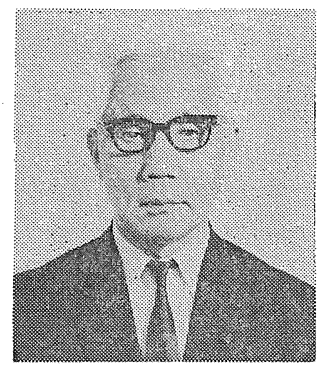

Yasota Kawakami

Kawaken Fine Chemicals Co., Ltd. (2-1, Kofune-chō, Nihonbashi, Chūō-ku, Tokyo)

\section{1 セッケンおよび合成洗剤の動向}

界面活性剤の動向を考える前にまずその主要製品であ るセッケンおよび合成洗剤の動向について述べる。

表-1 に世界の七ッケンおよび 合成洗剤の品種別生産 高を 表-2 に地域別生産高を示す。

世界のセッケンおよび合成洗剤の増産率は年平均 $3 \%$ で，合成洗剤だけのそれは 7\% である。セッケンおよび 合成洗剂の総生産高の $80 \%$ は世界の人口の $30 \%$ より

表-1 世界の品種別セッケン, 洗剤生産高

\begin{tabular}{|c|c|c|c|c|c|}
\hline & $\begin{array}{c}\text { 1960年 } \\
(\mathrm{t})\end{array}$ & $\begin{array}{c}\text { 1962年 } \\
(\mathrm{t})\end{array}$ & $\begin{array}{c}\text { 1963年 } \\
(\mathrm{t})\end{array}$ & $\begin{array}{c}\text { 1964年 } \\
(\mathrm{t})\end{array}$ & $\begin{array}{c}\text { 1966年 } \\
(\mathrm{t})\end{array}$ \\
\hline $\begin{array}{l}\text { 化 粧 } \\
\text { セッケン }\end{array}$ & 000 & 1,02 & 1,07 & $1,138,000$ & 1,26 \\
\hline $\begin{array}{l}\text { その他の } \\
\text { セッケン }\end{array}$ & 000 & $5,385,000$ & $5,411,000$ & 3,000 & 5,5 \\
\hline 小計 & $6,272,000$ & $6,408,000$ & $6,485,000$ & $6,496,000$ & 6,76 \\
\hline 合成洗剂 & $3,633,000$ & $4,505,000$ & $4,878,000$ & $5,210,000$ & $5,957,000$ \\
\hline $\begin{array}{l}\text { クレンザ } \\
\text { そおよび } \\
\text { その他 }\end{array}$ & $1,601,000$ & $1,714,000$ & $1,824,000$ & $1,763,000$ & 1,000 \\
\hline 総 計 & 11,50 & & & & \\
\hline
\end{tabular}

表-2 世界の地域別セッケン, 洗剤生産高

\begin{tabular}{|c|c|c|c|c|c|}
\hline & & $(t$ & & & $(t)$ \\
\hline & & & & & \\
\hline $\begin{array}{l}\text { 東 欧 } \\
\text { スニージ } \\
\text { ズラビ }\end{array}$ & 2,08 & 2,389 & 2,58 & 2,6 & 2,6 \\
\hline 小 & & & & & \\
\hline チメリカ & 3,2 & 3,5 & $3,674,000$ & $3,809,000$ & 3,9 \\
\hline 部了メ & & 00 & 0 & 00 & 3 \\
\hline 可アメリカ & 6 & 637,000 & 696,000 & 696,000 & \\
\hline ジ & $1,547,000$ & $1,639,000$ & $1,722,000$ & $1,739,000$ & $1,905,000$ \\
\hline オーストラ & 16 & 165,000 & 000 & 197,000 & 000 \\
\hline アフリカ & 443,000 & 465,000 & 495,000 & 540,000 & 609,000 \\
\hline 総 & & & & & 261,000 \\
\hline
\end{tabular}

多くない開発国で集中的に生産されている。世界の人口 1 人当たりの消費は年 $4 \mathrm{~kg}$ に当たる。1964 年で北米で は $18 \mathrm{~kg}$ (クレンザーなどを除外すれば $14 \mathrm{~kg}$ ), 西ヨー ロッパでは $10 \mathrm{~kg}$ (同 $8.2 \mathrm{~kg}$ ), 日本は $5.2 \mathrm{~kg}$ であっ た。またアジア，アフリカにおいては $1 \mathrm{~kg}$ 以下のとこ ろが多い。

日本は今や合成洗剤の生産高では米国についで世界第 2 位であり, セッケンと合成洗剤の合計の生産では米, ソ両国についで世界第 3 位となった。つぎに比較のため 表-3 に日本と米国のセッケンおよび合成洗剂の生産 高を示す。

終戦後の混乱期のため日本ではセッケン, 洗剤中合 成洗剂の占める率が初めて $10 \%$ を越光たのは 1959 年 で，米国は 1947 年で，その差は 12 年あった。 $50 \%$ 以上に達したのは日本では 1963 年, 米国では 1953 年で差は 10 年に, さらに $80 \%$ に日本は本年に達す る見込であり，米国は 1963 年で差は 5 年に縮まっ た。日本の全洗剤の生産増加率を年 7\% とすると昭和 50 年 (1975 年) には, 118 万 $\mathrm{t}$ になり,その内セッ

表-3 日本と米国のセッケンおよび合成洗浏の生産高

\begin{tabular}{|c|c|c|c|c|c|c|c|c|}
\hline & \multicolumn{2}{|c|}{ 米 } & \multicolumn{2}{|c|}{ 国 (千t) } & \multicolumn{2}{|c|}{ 日 } & \multicolumn{2}{|c|}{ 本 (千t) } \\
\hline & $\begin{array}{l}\text { セッ } \\
\text { ケン }\end{array}$ & 盒成 & 合計 & \begin{tabular}{c|} 
合洗の \\
此率 \\
$(\%)$
\end{tabular} & $\begin{array}{l}\text { セッ } \\
\text { ケン }\end{array}$ & 畣成 & 合計 & $\begin{array}{l}\text { 合洗の } \\
\text { 此率 } \\
(\%)\end{array}$ \\
\hline 1945 & 1,744 & 68 & 1,842 & 3.7 & 24 & - & 24 & - \\
\hline 50 & 1,342 & 655 & 1,997 & 22 & 96 & - & 96 & - \\
\hline 55 & 746 & 1,261 & 2,007 & 63 & 279 & 15.4 & 294 & 5.3 \\
\hline 60 & 579 & 1,787 & 2,366 & 75 & 347 & 86 & 433 & 20 \\
\hline 61 & 550 & 1,864 & 2,416 & 77 & 299 & 150 & 449 & 35 \\
\hline 62 & 563 & 2,005 & 2,568 & 78 & 259 & 189 & 448 & 42 \\
\hline 63 & 554 & 2,059 & 2,613 & 79 & 225 & 258 & 483 & 53 \\
\hline 64 & 527 & 2,126 & 2,689 & 80 & 201 & 302 & 503 & 60 \\
\hline 65 & 527 & 2,209 & 2,736 & 81 & 171 & 359 & 530 & 68 \\
\hline 66 & 525 & 2,268 & 2,793 & 82 & 161 & 430 & 595 & 73 \\
\hline 67 & 488 & 2,285 & 2,773 & 82.5 & 158 & 530 & 688 & 77 \\
\hline $70^{*}$ & 486 & 2,484 & 2,970 & 84 & 155 & 715 & 870 & 82 \\
\hline $75^{*}$ & 518 & 2,856 & 3,374 & 85 & 180 & 1,000 & 1,180 & 85 \\
\hline
\end{tabular}

* 推定 
ケンが 18 万 $\mathrm{t}$ ，合成洗剤が 100 万 $\mathrm{t}$ になる見込であり， そのとき米国はセッケンが 52 万 $\mathrm{t}$, 合成洗剤が 286 万 $\mathrm{t}$, 合計 338 万t になると推定されている。両者とも合成 洗剤の占める率は全洗剤の $85 \%$ になる見込で，1 人当 たりの消費量も日本は $10 \mathrm{~kg}$ 強に達し, ヨーロッパ諸 国に追付くが米国にはなお劣ることになるだろう。

近い将来日本の合成洗剤は生分解性のものに転換し， その主原料は LAS であることは確かであるが，10 年 先にいわゆる第 3 の洗片が出現するものとすれば，それ はへキスト社掠よびエッソ社の望みをかけているアルカ ンスルホネートであるか，あるいはシェブロン社および

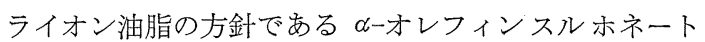
であるか, またはシェルおよびコノコ両社の期待する合 成アルコール洗鼡であるか子予断を許さない。著者はもし アルカンスルホネートの性能がさらに向上すれば最も有 望な合成洗剂原料であると思う。その理由は $n$-パラフ インから1工程でそれを造ることができるからである。 n-パラフィンのクラッキングで造られた ๙-オレフィン は副産物の経済的処方が解決されないと, 無制限に洗剂 原料として求められないのに反し, エチレンの大規模生 産によりチーグラー法による $\alpha$ オレフィンや合成アル コールは生産高が多くなるほど価格が低下し将来有望な 洗剂原料であろう。

パラフィン酸化で得られる第二アルコールは非イオン 活性洗剂原料として属目されている。そのエトキシサル フェートは特異臭の除去を解決しないと洗剤原料として 疑問であったが，いまや本邦の技術で解決されようとし ている。

\section{2 界面活性剤の動向}

\section{$2 \cdot 1$ 米国における界面活性剤の動向}

日本の界面活性剤の動向を考えるためにはまず合成洗 剤の場合々同じく米国の過去の実績および将来の発展の

表-4 米国に打ける界面活性郕生産高

\begin{tabular}{|c|c|c|c|c|}
\hline & \begin{tabular}{|l} 
隍イオン界面活 \\
性郕 $\left(10^{3} \mathrm{lb}\right)$
\end{tabular} & $\begin{array}{c}\text { 陽イオン界 } \\
\text { 面活性剤*** } \\
\left(10^{3} \mathrm{lb}\right)\end{array}$ & $\begin{array}{c}\text { 韭イオン界 } \\
\text { 面活性剂 } \\
\left(10^{3} \mathrm{lb}\right)\end{array}$ & $\begin{array}{l}\text { 合訪 } \\
\left(10^{8} \mathrm{lb}\right)\end{array}$ \\
\hline 56 & $\begin{array}{c}\% \\
872,000(75.9)\end{array}$ & $19,000(1.7)$ & 257 & 1,1 \\
\hline 57 & $(74.7)$ & $20,000(1.7)$ & 285,0 & 1,2 \\
\hline 58 & $2.0)$ & 2.4) & 25.6) & \\
\hline 59 & 1,067, & $36,075(2.4)$ & $400,424(26.6)$ & 1,50 \\
\hline 60 & 1,07 & (2.1) & 27.8) & 227 \\
\hline 61 & 1,237 & $45,125(2.6)$ & $25.5)$ & 1,7 \\
\hline 62 & 1,360 & $64,758(3.3)$ & (26.8) & 1,9 \\
\hline 63 & $(69.3)$ & $83,436(4.2)$ & $525,099(26.5)$ & $1,980,658$ \\
\hline 64 & $1,434,3$ & $98,348($ & $581,379(27.8)$ & $2,118,688$ \\
\hline 65 & $* 1,459,812(64.3)$ & $148,001(6.5)$ & $659,192(29.2)$ & $2,267,005$ \\
\hline 66 & $* 1,506,507(64.0)$ & $161,843(6.9)$ & $|685,693(29.1)|$ & $2,354,043$ \\
\hline
\end{tabular}

* 脂肪酸塩が統計にはいってきたの定除外した。

** 両性界面活性刘它含む (以下同様) その割合は 3 4\% で ある。
表-5 界面活性剤をベンゼン核を持つものと 持たぬものとに分類した表

\begin{tabular}{|c|c|c|c|}
\hline & $\begin{array}{l}\text { 総 } \\
\left(10^{3} \mathrm{lb}\right)\end{array}$ & $\begin{array}{l}\text { ざンゼン核を有 } \\
\text { する界面活性用 }\end{array}$ & 䩀ベソ面活性剤 \\
\hline 1961 & $1,729,000$ & $1,150,000(67 \%)$ & $579,000(33 \%)$ \\
\hline 62 & $1,949,000$ & $1,301,000(67 \%)$ & $648,000(33 \%)$ \\
\hline 63 & $1,981,000$ & $1,309,000(66 \%)$ & $672,000(34 \%)$ \\
\hline 64 & $2,118,000$ & $1,347,000(64 \%)$ & $771,000(36 \%)$ \\
\hline 65 & $2,267,000$ & $1,371,000(61 \%)$ & $896,000(39 \%)$ \\
\hline 66 & $2,377,000$ & $944,000(40 \%)$ & $1,433,000(60 \%)$ \\
\hline
\end{tabular}

方向について調べる必要がある。表-4，表-5 亿米国の 界面活性剂の生産高を示す。

表-4 からつぎの傾向があることを洞察することがで きる。10 年間に界面活性剤中陰 イオン界面活性剤の割 合は，76\% から 64\% に下がり，非イオン界面活性剤は $22 \%$ から $29 \%$ に，陽イオン界面活性剂（両性界面活性 剤を含む，以下同様） $2 \%$ から $7 \%$ に上昇した。この 傾向が将来も持続するものとすると 1975 年において陰 イオン界面活性剤は $50 \%$ ，非イオン界面活性剤は $40 \%$ ， 陽イオン界面活性剤は 10\% のシェヤーを占めるだろら。

表-5により明らかなように心゙ンゼン核を有する界面 活性剂は 1965 年の $61 \%$ 加ら 1966 年の $40 \%$ 亿激減し ている。これは 1965 年 6 月に米国で洗刘業者が自発的 に生分解性洗剂に切り換えたことの影響であると考えら れる。

米国の陰イオン界面活性剂の生産は年率 $4 \%$ で延びて きた。1966 年度におけるその内訳は，アルキルベンゼ ンスルホネート 40\%，リグニンスルホネート $30 \%$ ，エ ーテルサルフェート $9 \%$ ，アルコールおよびその他のサ ルフェート $6 \%$, その他の陰イオン界面活性剂 $15 \%$ で ある。

非イオン界面活性剤は 8.5\% で延びてきた。1966 年 度の内訳はェーテル型 $65 \%$ (ベンゼン系 $34 \%$, 非ベン ゼン系 $31 \%$ )，エステル 型 $21 \%$ (グリセリンエステル 系 10\%，ソルビタン系 4\%，その他 7\%)，アルカノー ルアミド型 $14 \%$ である。

陽イオン界面活性剤の生産は年 $27 \%$ で延びた。1966 年度の内訳は脂肪族アミン系 $37 \%$ ，第四アンモニウム 塩 $25 \%$ ，エトキシ化アミン打よび酸素を含むアミン類 $24 \%$ ，その他 $14 \%$ である。この内脂肪族アミンの生産 は 1963 年度より統計に記載されるようになり,わずか に 4 年後の 1966 年度には, 生産高が 4 倍になったこと に注目せねばならない。

\section{$2 \cdot 2$ 日本における界面活性剂の動向}

セッケン合成洗剂と同様に日本の界面活性剂は米国の 後塵を拝しているが，さらにより速いテンポで発展して いる。米国の統計は全部 100\% として記載されている が，一方日本界面活性剂工業会の統計は品種で純分がま 
表-6 日本の界面活性剤生産高 (100\% ベース)

\begin{tabular}{|c|c|c|c|c|c|c|}
\hline & $\begin{array}{l}\text { 鉱油系 } \\
(\mp t)\end{array}$ & $\left|\begin{array}{c}\text { アココー } \\
\text { 采おる } \\
\text { びその他 } \\
(千 \mathrm{t})\end{array}\right|$ & 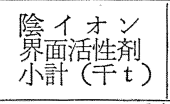 & 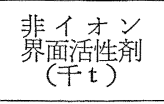 & 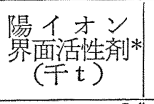 & $\begin{array}{l}\text { 総 計 } \\
\text { (千t) }\end{array}$ \\
\hline 1962 & 47,300 & 14,490 & $61,790(67.7)$ & $25,450(28.0)$ & $4,300(4.7)$ & 90,540 \\
\hline 63 & 64,300 & 16,180 & $80,480(67.7)$ & $33,400(28.1)$ & $5,050(4.2)$ & 118,930 \\
\hline 64 & 74,000 & 16,060 & $90,060(71.7)$ & $29,600(23.6)$ & $5,900(4.7)$ & 125,560 \\
\hline 65 & 88,400 & 18,520 & $106,920(72.6)$ & $33,600(22.9)$ & $6,580(4.5)$ & 147,100 \\
\hline 66 & 96,600 & 30,100 & $126,700(71.0)$ & $40,600(24.7)$ & $7,110(4.3)$ & 164,410 \\
\hline 67 & 96,300 & 35,650 & $131,951(68.7)$ & $52,400(27.3)$ & $7,640(4.0)$ & 191,990 \\
\hline
\end{tabular}

* 両性界面活性剂として約 $10 \%$ 前後を含む。

ちまちである。日本の生産高を $100 \%$ 品として示すため 著者は，アルキルベンゼンの消費高を 1.4 倍して 100 \% ABS の生産高とし,アルコール洗剤の純度を $40 \%$, 非イオン界面活性剤の純度を 70\%，陽イオン界面活性 剤の純度を $50 \%$ として計算し直して日本の界面活性剤 の生産高を米国同様 100\% ベースで示したものを 表-6 に示す。

表-6 から日本の界面活性剂の生産は年率 16\%（米国 は 7.6\%) で延び，内陰イオン界面活性剂は 15\%（米 国は 4\%)，非イオン界面活性剂は 20\%（米国は 8.5 \%)，陽イオン界面活性郕は 10\%（米国は 27\%）で生 長したことがわかる。陽イオン界面活性剤のみ異例のよ らにみえるが実は米国の統計には脂肪族アミン類を陽イ オン界面活性剂に含ませているに反し, 日本では含まれ ていないためである。日本で脂肪族アミンが工業的に大 量生産されるようになったのは，昭和 40 年 (1965 年) からで 2 年後の昭和 42 年には早くもその生産は 2 倍以 上となった。それゅえに界面活性剤の動向は, 日本は米 国とその帰を一にしていると結論することができる。

日本の界面活性剤が内輪に見積もって年率 10\% で将 来増産されるものとすると, 昭和 50 年には, $190,000 \mathrm{t}$ $\times(1.1)^{8}=400,000 \mathrm{t}$ に達する。各界面活性剤の割合も 米国と同様になるとすると

$$
\begin{aligned}
& \text { 陰イオン界面活性郕 } 20 \text { 万 t (50\%) } \\
& \text { 非イオン界面活性郕 } 16 \text { 万 t (40\%) } \\
& \text { 陽イオン界面活性剂 } 4 \text { 万 t (10\%) } \\
& \text { 合計 } 40 \text { 万 } \mathrm{t}
\end{aligned}
$$

となり, 陰イオン界面活性剤と非イオン界面活性剤の合 計 36 万 $\mathrm{t}$ の $1 / 2$ の 18 万 $\mathrm{t}$ は合成洗剂用に供せられ， 昭和 50 年における合成洗剤の生産予測量は前述のよう に 100 万七であるからその $18 \%$ に当たる。そして残り の 18 万 $\mathrm{t}$ 注一般工業用に供せられるだろう。陽イオン 界面活性剤についてはアスファルト乳剂用などの新規の 用途が米国同様に開発されるので, 昭和 50 年にはその 生産予測量の 4 万 $\mathrm{t}$ の達成も夢ではない。したがって日 本の脂肪酸の高圧還元による脂肪族アミン製造工業はさ らに大きい発展が期待される。

\section{3 スペシャリティ界面活性剂}

沉用の界面活性剤として大量の需要を求 めるためにはおのずからその価格に一定の 制限がある。陰イオン界面活性剂は 90 円/ $\mathrm{kg}$ 以下，非イオン界面活性剤では 160 円/ $\mathrm{kg}$ 以下，陽イオン界面活性剂では 300 円/ $\mathrm{kg}$ 以下, 両性界面活性剂では 500 円 $/ \mathrm{kg}$ 以下である。図-1 亿米国における界面活 性剤の価格と生産量との関係を示す。日本

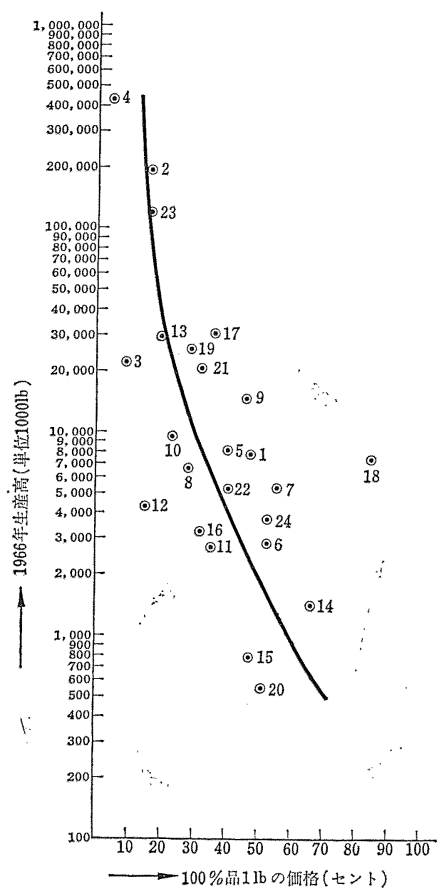

図-1 界面活性剤の価格と生産高との関係
価格と生産量との関係を示寸 図-1 の曲線は各種のプ ラスチックスにもまったく同一な曲線の関係がある。つ まりこの曲線は社会的需要曲線であり, 各界面活性剂間 に広い意味での代替関係があるのでこのような傾向がで てくると思われる。

界面の諸性質たと光ば乳化，分散，起ホウ，浸透，湿 潤などの内いずれか一つの性能が比類なく優秀である界 面活性剤はその価格がたとえ汎用界面活性剂の標準価格 より高くても特殊な用途に需要がある。これらをスペシ アリティ界面活性剤といら。つぎにその二, 三のものの 動向を示す。

\section{1 アルカノールアミド}

ヤシ脂肪酸のジェタノールアミドの価格は日, 米とも 240 円 $/ \mathrm{kg}$ であって, 非イオン界面活性剤としては高い が起ホウ安定剤となる特性を持ち, 初めはそのモうエタ 
ノールアミドが粒状洗剤に大いに用いられたが，米国で は 1963 年に, 日本では 1964 年に, あわコントロール 品が普及するようになったため, その消費は激減した。 しかしジェタノールアミドは液体洗剂およびシャンプー 用に年々需要を増している。その消費量は液体洗剤 100 に対し米国では $2.5 \%$ ，日本では $1.5 \%$ である。米国の 液体洗剈の濃度は $30 \%$ 以上であるのに反し，日本のは $20 \%$ 以上であるから結局の配合割合には両者間に大差 はない。

エトキシ化モノエタノールアミドは数年前に欧米およ び日本で開発され液洗の手荒れ防止用または化粧セッケ ンの過脂肪剂として有望になった。

\section{$3 \cdot 2$ リン酸エステル系界面活性剂}

エトキシ化アルキルフェノールまたはエトキシ化高級 アルコールのリン酸エステル塩は陰イオン活性であっ て，その HLB が広い範囲で変えられる唯一のものであ る。乳化剤として, ヘビーテューティ液体洗㓮として, ドライクリーニング用洗剤としてあるいは防セイ剤, 帯 電防止剤にもなる。米国における生産高の趨勢を 表-7 に示す。

表-7 米国におけるリン酸エステル系界面活性剂の生産高

\begin{tabular}{rlc}
\hline 1962 & $2.14\left(10^{6} \mathrm{lb}\right)$ & 単価 $69(\phi / \mathrm{lb})$ \\
63 & 2.54 & 68 \\
64 & 3.66 & 68 \\
65 & 5.18 & 63 \\
66 & 8.79 & 53 \\
\hline
\end{tabular}

生産高は 4 年間に約 4 倍になり, 単価は逆に初めの 77 \%に下がった。生産が増して単価が下がるのはスペシャ リティ界面活性剤の開発上最も好ましい現象である。本 邦でも最近国産化されたが, 米国の後を追ってきっと発 展するだろら。

\section{3 -3 アラノン系両性界面活性剂}

第一級アルキルアミンにアクリロニトリル付加しケン 化すれば一般式 $\mathrm{RNHCH}_{2} \cdot \mathrm{CH}_{2} \mathrm{COOH}$ なる両性界面活 性剤が生ずる。原料のいずれも将来安くなる見込充分で あるから最も有望な両性界面活性剂である。この種のも のの一つとして, N-メチルラウロイルアラニンをわれ われが開発した。刺激がなくアワ立ちが良いからシャン プー原料などに有用である。

\section{4 アセチレン系界面活性剤}

市販名 Surfynol として近年開発された。一般式は,

$$
\begin{array}{r}
\mathrm{C}_{4} \mathrm{H}_{9}-\mathrm{C}-\mathrm{C} \equiv \mathrm{C}-\mathrm{C}-\mathrm{C}_{4} \mathrm{H}_{9} \\
\left(\mathrm{OC}_{2} \mathrm{H}_{4}\right)_{n} \mathrm{H} \quad\left(\mathrm{OC}_{2} \mathrm{H}_{4}\right)_{m} \mathrm{H}
\end{array}
$$

である。

酸掞よびアルカリに安定な非イオン界面活性剤であ る。特長として湿潤性が強大でその $0.15 \%$ 水溶液は, $20 \sim 70^{\circ} \mathrm{C}$ の温度範囲でモメンを瞬間に妨すことがで きる。低起ホウ性工業用アルカリ洗剤に 2 3\% 加えた
ら成績抜群であった。しかし価格が 800 円 $/ \mathrm{kg}$ であるこ

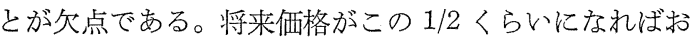
もしろいと思ら。

\section{$3 \cdot 5$ フッ素系界面活性剂}

踈水基は極端に安定なフルオロカーボン鎖より成り， それに各種の親水基を組み合わせてできた界面活性剤で ある。 $3 \mathrm{M}$ 社の Fluorad が代表的な商品である。水溶 性のものも, 油溶性のものもある。高温, 強酸, 強アル カリ, 酸化剤, 還元剤に安定な界面活性剤である。柾水 性と疎油性を兼螎えているので金属閒の潤滑性能を増 すこと他に比類するものがないから，潤滑油添加剤とし て賞用されるし, その希薄水溶液は表面張力を 18 dyne/ $\mathrm{cm}$ 以下になる特性を利用し，床のつや出しエマルショ ン製品のレベリング剤として欠くことができない。それ ゆえに価格が 10 万円 $/ \mathrm{kg}$ であっても使用されている。 また後章で述べるように織物のソイルリリース仕上剂と して最近活用されようとしている。

\section{$3 \cdot 6$ その他}

プルロニック系非イオン界面活性剤はその HLB が細 かくテーラーメイドに選ぶことができるから，価格が 300 円/kg 以下になれば Tween やSpan の強敵になる かも知れない。

ショ糖エステルがステアリン酸モノグリセリドより安 くなれば，食品用の乳化剤や洗浄剤として大いに発展す るだろら。

\section{$3 \cdot 7$ 研究の動向}

界面活性剂に残された研究の分野は，新規の界面活性 剤の探求よりもむしろ, 現在活用されているものの化学 構造と, その界面活性との関係を, 地道に検討する研究 が学界で必要であり，特定の用途に最適な界面活性剤の 配合の研究が工業界で大切であると思う。

\section{0 年度において 合成洗剂, 織物, 電気 洗タク機業界はどうなるか}

表題について本年 3 月末から 4 月初めに A.O.C.S.の シンポジウムが開かれた。その大要をつぎに示す。

\section{4・1 新原料としての高級アルコールおよび 合成脂肪} 酸 Moffett, DeAcefic (シェル化学株式会社)

洗剤留分である $\mathrm{C}_{12} \sim \mathrm{C}_{18}$ の合成第一アルコールは米国 に 4, 西欧に 1, 合計 5 のプラントが稼動し 1967 年度 の生産高は $175 \mathrm{~m} .1 \mathrm{~b}$ と見積られている。その内 3 工場 は米国内にあり，シェル社の特許でチーグラー法で稼動 している。

価格と性能とを合わせ考慮すると合成アルコールの方 が油脂を原料とする高級アルコールよりもすぐれてい る。

最近稼働した Geismar (ルイジアナ州) の工場は年 $150 \mathrm{~m} .1 \mathrm{~b}$ の能力を持ち 1 工場で 1967 年度の全アメリカ 
の生産高に匹敵している。また西欧および日本でも合成 アルコール工場が稼動するようになった。脂肪アルコー ルから脂肪酸を造ることについては, アルカリ溶融法が 最良のコマーシャルな方法であると思う。飽和脂肪酸を 工業的に応用するに当たり高純度の品を要求されるから パラフィン酸化の脂肪酸中に含まれるヒドロキシ, また はオキシ酸を経済的に完全に取ることが困難であるから である。シェルの方法で造られた合成脂肪酸の内 $\mathrm{C}_{12} \sim$ $\mathrm{C}_{15}$ のものを機械練化粧セッケン原料として少量用いる とまったく異なるポリモリフィリックフェーズを造るの で興味がある。しかしパラフィン酸化で脂肪酸を造るこ とは鉄のカーテンの向こう側で $6 \sim 8$ 工場で年間 $10 \mathrm{~b} .1 \mathrm{~b}$ の量が生産されている。

\section{$4 \cdot 2$ 新纎維および織物の出現と消費者の要求}

Fred, Fortess（セラニーズ繊維会社）

織物工業ではポリエステルとモメンの混紡品が過去に おいて急激な発展をしたし, 将来も一そら発展の可能性 のあること, 現在のパーマネントプレス加工品の上にさ らにソイル, リリース仕上加工品も完成されたこと, で きあがりの織物も従来の紡績法によるほかに編上法によ るものも造られるようになったことのよらな各種の技術 革新は洗剤業界を考慮せずに消費者の要求に答えるため になされたのである。それゆえに洗剤配合研究者や洗夕 ク機のメーカーは織物工業の革新に遅れを取らぬように して苜いたい。

\section{$2 \cdot 3$ 織物工業の技術革新が洗剂配合に及ぼす影警に ついて}

Hunter, Roga (コールゲートパーモリーブ社)

1963 年にパーマネントプレス品が出現した直後カウ スがモメンのシャツからちぎれて取れる苦情が出た。こ れはその加工のためその強度が洗タク中のまたは乾燥中 の摩耗に抗することができなかったためである。65\% モメン-35\% ポリエステル混紡品では樹脂加工されたも のでもその摩耗に打ち勝つことができた。またポリエス テル混紡品のケイ光漂白劑も開発された。なおりイルリ リース加工品の出現に応ずるために洗剤配合の研究を行 ない，その結果をつぎのように報告した。

試験に使った布は 4 種であって

$$
\begin{aligned}
& \text { 1. モメンのブロード } \\
& \text { ․ } 65 \% \text { モメン-35\% ポリエステルのブロード } \\
& \text { 八. ロ.のパーマネントプレス加工品 } \\
& \text { =. ハ.のソイルリリース加工品 }
\end{aligned}
$$

洗浄力試験に使った洗剤の配合はつぎのようである。

$$
\begin{array}{lc}
\text { 界面活性剤 } & 15 \sim 20 \% \\
\text { ビルダー } & 25 \sim 35 \% \\
\text { ケイ酸ナトリウム } & 7 \% \\
\text { 再污染防止剤 } & 0.6 \% \\
\text { 水分およびボウ硝 } & \text { 残分 }
\end{array}
$$

洗浄力試験は $0.15 \%$ の濃度で, 温度 $49^{\circ} \mathrm{C}$, 硬度 150 $\mathrm{ppm}$ の水を用いて, 試験布は人工の皮脂で污染したも
のを，家庭用洗タク機で洗って行なった。

その結果, 各種の陰イオンおよび非イオン界面活性剂 の性能を比較したらわずかに非イオン界面活性剤がプラ スであった。

4 種の布の間の差異もまた微小であったが LAS を使 ったときにはその濃度の影響が認められ，とくにイ.ロ． の布では有効成分の低いものの方がマイナスであった。 しかし非イオン界面活性剤では濃度の影響は認められな かった。

イ・ロ.の布について AOS は LAS よりわずが良 い成績を示した。また LAS や AOS に非イオン界面活 性剂を添加しても相乗効果は認められなかった。

ビルダーの影響については S.T.P.P. 中に N.T.A.を 数\%加えても口.八.の布を洗う場合いくらかのプラ スを認めたがニ。の布については差別がなかった。

\section{$4 \cdot 4$ 新しい化粧セッケン}

Jungerman, Herrick（アーマーグロサリー製品 会社)

化粧セッケンの製法には過去数十年間革新はなかった が，つぎの六つの進歩がなされた。1）新浮セッケンの 出現，2）コンバー または 全合成固型化粧セッケンの出 現，3）デオーダラント化粧セッケンの発展，4）包装の 改良，5）セッケン生地製造法の連続化，6）近代化され たセッケン素地の仕上げ方法, 以上である。5) と 6) と で化粧セッケンの製造が高速化した。3）のデオーダラ ントセッケンは 1940 年から出現した。そして広い範囲 の殺菌スペクトルを持ち, 安定で皮膚に多く吸着し, か つ安全性の高い単一または混合殺菌剂が選定された。最 も普及している.もの G-11, トリブロムサリチルアニ リド，八ロゲン化カーバニリドで最近イルガサン $\mathrm{CH}-$ 3565 (2,4,4'-トリクロル-2-オキシジフェニルェーテ ル）が開発された。多くのサリチルアニリドまたは八口 ゲン化フェノール化合物には光線過敏症の恐れがあり， とくにビチオノールにはその恐れの多いことが認められ た。

セッケンに各種の界面活性剂を添加しセッケンかすの 生じないようにしたコンバーも市販されるようになった (注。エトキシ化アルカノールアミドが注目されてきた)。

全合成洗剂の化粧セッケンにはなおいろいろな問題が 残されている。使用可能な界面活性剤としては，1)ア シル化イセチオネート，2）アルキルグリセリルエーテ ルサルフェート，3）脂肪アルコールサルフェート，4) モノグリセリドのサルフェート，5）反-スルホパルミテ ートメチルエステル，6) エトキシ化アルコールのリン 酸エステル塩，7）ラウリルー $\beta$ ラーアランなどがある。

$\mathrm{C}_{11} \sim \mathrm{C}_{15}$ 範囲の合成脂肪酸 も将来有望な界面活性剤 およびセッケン原料となることを指摘した。

セッケン生地製造の連続法も大いに進歩したが，いま 
なお大多数の工場ではバッチ式を採用している。セッケ ンの包装速度は 1970 年度に 300〜350 個/min になるた ろう。

\section{5 電気洗タク機のハードウェヤーにおける変化}

Donovan (ゼネラルエレックトリック社)

1967 年度に洗タク機 4.1 百万台, 乾燥機 2.6 百万台 とが売れた（家庭用耐久消費財の $30.6 \%$ ) 現在の洗夕 ク機は $7 \mathrm{~kg}$ の負荷 (10 年前は $4.5 \mathrm{~kg}$ ) で 4 サイクル

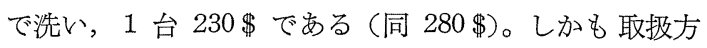
法が著しく進歩した。とくにかくはん方法が重要視され ている。しかし超音波を使らことは 5〜10 年後といえど も家庭用としては実現しないだろう。

家事に費す総時間の内洗たくは $17.5 \%$ に達していて その内の $1 / 2$ はアイロンかけにあるので, 主婦としては アイロンかけの時間を節約することをとくに望んでい る。それゆえに織物のパーマネントプレス加工は必要と なった。

一般に家庭で洗たくする織物の種類が年々ますます増 加しつつあるので電気洗タク機はそれに応ずるため作用 や構造がさらに複雑化せね㞧らなくなった。一方エン ジニヤーの側では洗タク機がさらに多くの複雑なメカニ ズムになると主婦の機械の取扱に暗いことと矛盾をきた すので, 将来の洗タク機は高度にオートメーション化さ れるよう設計するようになった。

現在自動方式で漂白荗, ソフター, 洗剤および酵素剤 を加えて 4 サイクル（2サイクルは予洗，2サイクルは 本洗浄) で作動する洗タク機が設計中である。各処理剤 を電磁バルブで一定量を洗タク機に自動的に注入するよ らになっている。もし洗剤メーカーが現在の粒状の洗剤 を液状のものにしてくれたら, 機械の製作費は約 20 \$安 くなる見込である。

\section{$4.6 \mathrm{AOS}$ を原料とする新家庭用洗剂}

富山, 高尾, 森, 関口（ライオン油脂株式会社） 日本の 1970 年度のセッケン, 洗剂の生産高は 1.95 b.1b になる見込でその内合成洗剂は $82 \%$ ，化粧セッケ ンは $12 \%$ になるだろうと予測し，合成洗剤の生分解性 への転換は 1965 年に始まり 1968 年に 80\%，1970 年 に $85 \%$ に達する見込であると発表した。

1965 年に $\alpha$-オレフィンがコマーシャルベースで自由 に得られるよらになったので, 生分解性洗剤として $\alpha-$ オレフィンスルホネートを家庭用合成洗剤とする研究に 着手した。

ワックスクラッキングによる $\alpha$-オレフィンは大量に 供給可能でありかつ経済的である。AOS はその性能が LAS やAS に劣っていない。ただ重要なことは日本の 小売店頭でどの洗剤も直面しなければならないことは年 2 回の高温高湿になる季節があり，かかる厳しい条件の 下に耐えられるかどうかという点である。研究に供した ものは AOS 20\%, STPP 30\%, Na シリケート 5\%, 水分 $10 \%$ ，残分ボウ硝より成る試作品であった。活性 分を $\mathrm{AOS}$ LAS にしたものについて洗浄力, ホウ 高，貯蔵安定性を実用に近い条件でテストし同時に市販 品についても比較した。AOS は他の洗剤よりも最もケ 一キングしやすかったが，この欠点は配合の調整（アン チケーキング 剤の添加) で克服した。他の洗剤よりも AOS 製品は洗い上りの織物の手触りがやわらかであっ た。生分解性の測定では AS に近く LAS よりも良好 であった。

300 人の主婦によるパネルテストで本製品は他の洗剂 よりもすぐれていると認めたものが $75 \%$ ，洗タク物の 触感が良いと認めたものが $55 \%$ あった。

(昭和 43 年 11 月 16 日受理) 